\title{
Right Ventricular Outflow Tract
}

National Cancer Institute

\section{Source}

National Cancer Institute. Right Ventricular Outflow Tract. NCI Thesaurus. Code C127648.

The funnel-shaped structure through which blood flows from the right ventricle into the pulmonary trunk. 